\title{
Erratum: Religious views on the origin and meaning of COVID-19
}

\section{Authors:}

Tanya Pieterse ${ }^{1}$ (D)

Christina Landman ${ }^{1}$ (D)

Affiliations:

${ }^{1}$ Research Institute for

Theology and Religion,

College of Human Sciences, University of South Africa,

Pretoria, South Africa

\section{Corresponding author:}

Tanya Pieterse,

tanyap@global.co.za

Dates:

Published: 21 June 2022

How to cite this correction: Pieterse, T. \& Landman, C., 2022, 'Erratum: Religious views on the origin and meaning of COVID-19', HTS Teologiese Studies/

Theological Studies 78(1), a7229. https://doi. org/10.4102/hts.v78i1.7229

\section{Copyright:}

C 2022. The Authors. Licensee: AOSIS. This work is licensed under the Creative Commons Attribution License.
In the published article, Pieterse, T. \& Landman, C., 2021, 'Religious views on the origin and meaning of COVID-2019', HTS Teologiese Studies/Theological Studies 77(3), a6283. https://doi. org/10.4102/hts.v77i3.6283, the title contained a spelling error, namely 'COVID-2019'. The spelling error was unintentional. As a result of this, the title is corrected to read 'Religious views on the origin and meaning of COVID-19'.

The publisher apologises for this error. The correction does not change the significance of study's findings or overall interpretation of its results or the scientific conclusions in any way. 


\section{Religious views on the origin and meaning of COVID-2019}

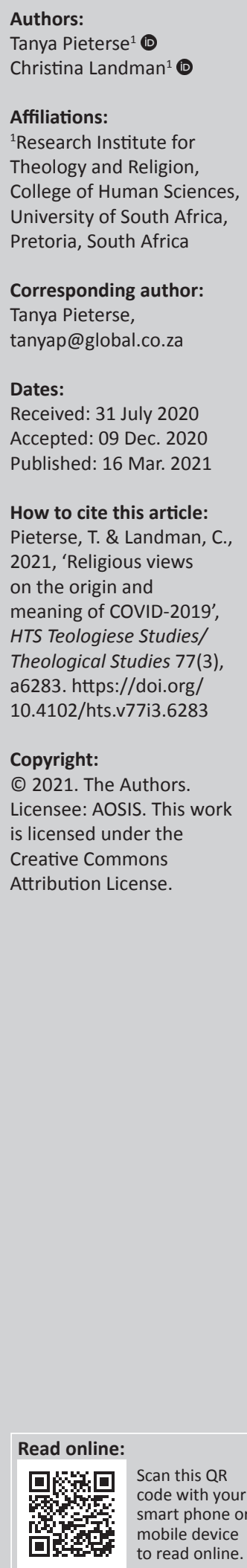

For ages, natural disasters, war and disease have been part of life, sharing themes of not only adversity, fear and death, but also hope. The year 2020 brought a new threat in the form of coronavirus disease 2019 (COVID-19), which challenged what humankind understood of all they knew and believed. The significant difference today is the role of the media in sharing news and opinions on this disease that threatens not only lives, but also spiritual well-being. In this study, we focus on people's religious views on the origin and meaning of this invisible threat to establish how this pandemic impacts on people's belief systems. The 20th century was marked by a shift whereby actions and events are intellectualised to rationalise cause and effect, and the philosophical theodicies are regarded to limit our critical reasoning. This study, however, shows that COVID-19 reactivates this debate in that it surpasses logic and rational thinking. Data are collected by means of comments, discussions and opinions shared on numerous social media platforms. During times of adversity, the same rhetorical 'who' and 'why' questions are asked and in this regard, theodicy as a philosophical framework informs this study. Applying a narrative inquiry, data are interpreted and three themes are identified, namely COVID-19 is an act God, COVID-19 has nothing to do with God and God remains in control amidst a devastating pandemic. The sample for this study is random and the medium used allows for representativity in terms of age group (18+), gender, race, religious affiliation of South Africa, but not limited to this country.

Contribution: This article provides insight into renewed debates on religious views on pandemics and suffering in the context of COVID-19. It contributes to an understanding of different perceptions on the origin of this disease, how people make sense and find meaning in being part of a global discourse.

Keywords: COVID-19; social media; religious meaning-making; theodicy; spiritual wellbeing; religious discourse; narratives.

\section{Introduction}

\section{Aim of the study}

The aim of this article is to report on the results of a study conducted from April 2020 to July 2020 during the worldwide peak of the coronavirus disease 2019 (COVID-19) pandemic. Over centuries, humankind has been threatened by various epidemics, pandemics, wars and natural disasters. Coronavirus disease 2019, however, is the first of its kind for many people around the globe. It causes hardship and fear, and many narratives of disbelief and disillusionment were shared during our study. Information on the scientific and biological causes and emergency instructions on caution and prevention is widely available. This is supplemented by live media updates on new positive casses, deaths, recoveries and economic shutdowns in all affected countries. There is also a flood of opinions, views and theories of the causes of this virus shared on numerous media platforms, contributing to the perception of this virus being unique and different from previous similar global events. Just as scientists search for answers to explain the characteristics, transmissions and possible mutations of this virus, so do ordinary citizens try to find answers to the 'what' and 'why' of this phenomenon invading our lives at so many levels (Reuters 2020; WHO 2020a).

Narratives in the form of written interactions shared on various media platforms serve as our main source of data. The findings of our engagement and contribution by numerous commentators are interpreted within a narrative philosophical framework to determine how people make sense of the pandemic (Clandinin 2007:5). These results will be discussed aiming firstly to provide

Note: Special Collection: South African Science and Religion Forum (SASRF), sub-edited by Wessel Bentley, UNISA. 
insight into people's religious views on the origin of this pandemic, secondly to describe the meaning people attach to their suffering caused by this pandemic and thirdly to explore how this pandemic impacts on their belief systems.

During times of adversity, as with this pandemic, the same rhetorical 'who' and 'why' questions are asked, and in this regard, theodicy as a philosophical framework was applied to inform our navigation of the data. After applying a narrative inquiry to the data collected, three themes emerged namely, COVID-19 is an act of God, COVID-19 has nothing to do with God and God remains in control amidst a devastating pandemic. These themes will be discussed by paraphrased and summarised representations of participants' contributions.

\section{Research population}

The numerous media platforms used in this study allowed for a wide range of participants to be sampled. For this research, engagement was not through actual face-to-face interaction, or the typical researcher-interviewee scenario in a formal interview set-up, and we will therefore refer to 'participants' as the contributors to this study. The range of social media used ensures that the demographics of our sample are as representative as possible, providing an adequate range in terms of age (18+), gender, race, language, religious tradition, denomination, spiritual belief system and even country. The typical demographics could in some instances be determined from visible characteristics, biographical information shared, the composition of a selected page or particular group and the content of discussions. However, as researchers, we handled all information with strict recognition of confidentiality and anonymity, and these were secured, as guided by the Social Media Research Group (SMRG) and other such bodies $(2016: 7,18)$.

\section{Background discussion A rapid virus in a world in slow motion}

From afar, citizens in different parts of the planet watch as the world slowly shuts down. A medical condition that initially started with typical pneumonia symptoms of patients in Wuhan, China, was first reported by the World Health Organization (WHO 2020b) on 31 December 2019. Early in January 2020, it was identified as a coronavirus, named by the International Committee on Taxonomy of Viruses as a 'severe acute respiratory syndrome coronavirus 2 (SARS-CoV-2)', because it is genetically related to the coronavirus responsible for the SARS outbreak of 2003, and was named by the WHO as COVID-19 ('CO' - 'corona', 'VI' - 'virus', 'D' - disease and 19 refers to the year 2019) (WHO 2020c).

This virus spread rapidly, infecting the world as far as Greenland, causing fatalities in almost all countries (Worldometers 2020). Over centuries, humankind has been exposed to numerous adverse events, such as natural disasters, war, disease and viruses or bacteria, such as HIV or Ebola, which are still prominent. Coronavirus disease 2019, however, is an invisible enemy that impacts all people and society, not only their health but globally threatens also lives and livelihoods, economies and politics. Scientists and medical professionals share their expertise on how this virus transmits between people, mutates and affects patients' health. Clear guidelines are provided concerning social distancing, self-isolation, quarantine, wearing of masks, washing hands and sanitising (Meylahn 2020:2). Facts, figures and newsfeeds of rising active cases and deaths are reported in live updates on various news platforms from the WHO, worldometers.info, Aljazeera.com, eNCA.com, CNN. com, news.sky.com, to Twitter, YouTube and Facebook, only to name a few.

In contrast with the speed and vastness at which this pandemic spreads, the world is slowing down. In a couple of months, countries, cities and towns were locked down, economies were shut down and schools and businesses were closed. People's lives came to a halt, irrespective of social standing, financial performance, age, race, gender or qualification. We are now all part of a horror movie, playing in slow motion, where we feel like inexperienced actors, without a script, in a surreal world. With personal contact prohibited and workplaces, churches and restaurants closed, people globally had to revert to alternative means of communication, communion, interaction and gaining information.

Social media has become an effective tool to serve as an interim alternative. Although not ideal, it provides space to engage, cultivate collaboration and promote debate on other burning social issues, which otherwise might have been restricted (Mushwana \& Bezuidenhout 2014:63). During this pandemic, social media serve as a great escape to air views and frustrations to connect with people holding similar views as well as dissimilar opinions, which is what allows for the richness of the discourse of this study.

\section{Religious and spiritual questions during COVID-2019}

Coronavirus disease is often compared to other similar adversities, such as the Spanish Flu between January 1918 and 1920, that was estimated to have infected 500 million people in the world (Newman 2020), and the Black Death during the 14 th century that caused almost $50 \%$ of deaths in Europe. The main difference between these pandemics is that the first two are caused by a virus and the latter by bacteria. Information during earlier times was limited and causes were attributed to poisoned air, where terms such as transmissible and infectious diseases were non-existent. Theories were also constructed of countries or populations deliberately causing diseases (University of Rhode Island 2020).

Many debates around the current pandemic include an array of topics, of which one prominent subject relates to the focus of our study on religious or spiritual content relating to COVID-19. Engagements revolve around the origin of the pandemic, who and what cause this virus, the hidden 
messages to the world and its inhabitants by some divine intervention. Conversations also include themes such as control, evil-doing, punishment, why the suffering is allowed and how long it will last.

During our engagement with the data sources, we identified many comparisons made with the suffering of the biblical character Job, a virtuous man of God who had to endure so much despair. The discourse at that time is not much different from today. Job's suffering must have been caused by his secret sins. How can such sadness be bestowed upon such a loyal servant? God's wrath was a mystery (Chester \& Duncan 2009:310; Du Rand 2016:180). Today, with the COVID pandemic, people are confronted with the same questions. In addition to that people are also unsure about the existence of God. He is not even there for an obedient believer, such as Job, how can we trust him for being there for us in these times? (Scott 2020:321). These questions raised and references made inevitably lead us, as researchers, to the continuous debate which theologians and philosophers have struggled with for centuries, namely what causes human suffering and evil in the face of an ever-present, loving, omnipotent God? (Du Rand 2016:169; Rouzati 2018:4). For centuries, it has raised similar questions on why bad or evil is allowed, and the issue of 'innocent suffering' that remains a theme of many religious narratives and therefore various theological responses (Chester \& Duncan 2009:304). One such response, also referred to as theodicy, as initially formulated by Gottfried Leibniz in 1710, presupposes that a 'higher good exits' in a world created as the 'best of all worlds' (Du Rand 2016:169). In the current pandemic, his creations, therefore, do not understand why, if God is the Creator of all, and who therefore foresees all things, He permits such evil to happen and does not prevent it (Leibniz 2005:58; O’Mathúna 2018:32). Theodicy further relates to reconciling the concept of a caring, just God, with the reality of the simultaneous presence of evil (Chester \& Duncan 2009:304). Theodicy, as Conradie (2005:408) states, is the desperate need in times of suffering to justify God's existence, omnipotence and love.

These presuppositions are identified in the narratives shared by numerous sources on the various platforms consulted in this study, which underpins the discussion of our findings. In an attempt to address the aim of this study, namely, to provide insight into people's religious views on the origin of COVID-19, to describe the meaning people attach to the suffering caused by this pandemic and to explore how this impacts on their belief systems, the following themes were identified: COVID-19 is an act of God, COVID-19 has nothing to do with God and God remains in control amidst a devastating pandemic.

\section{Methodology}

Research has itself been affected by the pandemic and methods and methodologies have had to adapt to answer the need for continued communication, collaboration and social and physical scientific discourse (Byrnes et al. 2020:1). The application of social media has gained momentum over the past decades as a novel method of data collection, so the analysis of social media, and the data it provides, helps us not only to evaluate the social impact of such research, but also the effects of social media on society (Pulido 2020:1). With the written word being the first revolution in providing information, we now have entered the digital media revolution. Various social media platforms have shown an unparalleled global expansion that transforms how people communicate and interact (Pulido 2020:2). Social media, according to the SMRG (2016:3), can be defined as web-based platforms used by other individuals, groups and institutions to produce content. This enables users to interact, share, discuss and debate on issues of mutual concern.

\section{Data collection}

Across the globe, vast amounts of information are shared on numerous digital platforms, such as various news networks, Twitter, Facebook, YouTube and television. These media are now the avenue where communities join discussion groups to share views and voice opinions on this global phenomenon. Our research is also influenced by this. Because distance and isolation might previously have been more limiting, electronic communications have now become the means of remote data collection (Byrnes et al. 2020:1). Utilising these means of data sources also allows one to join platforms of various interest groups, denominations and religious affiliations.

Discussions are conducted in electronic open spaces that are mostly accessible and visible to everyone, everywhere. Participants have the choice of unlimited media avenues of their choice and can share their opinions on more than one platform. This medium allows for discussions to be anonymous, incognito or under witty profile names or Twitter handles, and issues of importance to participants trend under hashtags. Given the topic of our study, we are able to be selective with the networks accessed to ensure trustworthiness and relevance (SMRG 2016:19). Researching this study topic does not focus on fake news and conspiracies that are rife during this pandemic. This study also does not entail a search for scientific facts, correct medical representations and answers on this pandemic. It is a study concerned with the social sciences and dialogue about COVID-19 as religious or spiritual discourse, which allows for an array of opinions and open debates. This method of data collection, however, requires rigour in terms of the volumes of sources to consult, and a large amount of data to process, eventually to analyse and interpret.

\section{Interpretation of data}

As mentioned earlier during our research, data were collected by means of the written representations of participants, and not through the typical one-on-one scenario of a formal researcher-participant engagement. Our engagement was, however, as distant partners in a journey with a new phenomenon named COVID and its religious or spiritual navigation within these challenging times. Some data were also collected from YouTube messages on the topic of study. 
The written comments used are not mere once-off statements, but form part of a larger discussion on a particular platform consulted. Adopting this method helps the researchers to be part of persons' lived experiences that shape their views.

The written word, like the spoken word, serves as a valuable source for a narrative inquiry, which enables us as researchers to understand individuals' lived world. Following this philosophical framework, this research focusses on individuals' holistic experiences, encompassing their religious, cultural and social context (Clandinin 2006:51), an approach regarded as most appropriate to achieve the aims of our study. It is the framework also often applied in conducting social sciences research, relating to disciplines such as theology, psychology, history, literary theory and philosophy. Through participants' written words, as explained by Landman and Pieterse (2019:2), researchers become cotravellers in the COVID journey and position themselves within this pandemic. The religious discourses identified whilst partnering with the research sources reflected the embedded narratives within which people think and live in making sense of COVID and what they regard as the origin thereof, and thus also allow their 'voices' to be heard.

\section{Ethical considerations by using social media as a source of data}

Although it is acknowledged that in conducting social research, various ethical principles need to be considered, social media research has brought new dimensions to the field. As an emerging source of data, knowledge, insights and consequently guidelines are also evolving (SMRG 2016:16). As researchers, we took cognisance of guidelines on social media research ethics developed by amongst others the SMRG, British Psychological Society (BPS) (2017) as well as the Economic and Social Research Council (Townsend \& Wallace 2016). Aspects of this research also align with international guidelines on ethics for social studies. The difference, however, lies in the fact that in this research open-access datasets are used that are part of the international public domain. Because no formal consent is acquired and is almost impossible to obtain, researchers are referred to the terms and conditions of all platforms that users, by mere using social media, agree to. By accessing, commenting on or signing-up on any media platform, one agrees that any written or verbal content produced becomes public domain and forms part of a larger data set. However, great care is taken in this study not to use information where users expect some degree of privacy (Townsend \& Wallace 2016:5). This is a matter that was given due consideration in this study and could effectively be managed by the researchers' experience and knowledge of the medium used as a source. Further to this, BPS (2017:7) states that with social media platforms, where it can be reasonably argued that 'there is likely no perception and/or expectation of privacy' coupled with the type of data gathered, and the processing thereof as in this study, it may be justifiable to waive consent.
Furthermore, aspects such as public versus private data are explained where private can refer to platforms that are password protected, for example, private Facebook accounts, and groups where membership to join is subject to approval or access granted. Sources from personal Facebook pages are also not utilised in this study, particularly for this reason. Data that form part of the public domain refer to open discussions on, for example, Twitter where opinions and debates are conducted by using hashtags to broadcast views and invite participation. Such topics are then trending, thereby indicating the relevance and popularity of the subject matter (Townsend \& Wallace 2016:5). Newsfeeds on various news networks are also a media platform where remarks, often by, for example, politicians and religious leaders, become open sources of significant debates, which were found relevant in our study as well.

In this study, the core elements of ethical research were upheld in terms of, amongst others, respecting the sources and contributors, due consideration in handling sensitive information (Townsend \& Wallace 2016:11; University of South Africa [Unisa] 2016:16). Religion in the context of COVID with a global impact is current and the debates are regarded as very important. For this study, it is regarded that people, in sharing views and participating in debates, contribute to a feeling of communion, finding meaning during this challenging time and being part of a bigger purpose and discourse.

Another important issue, as highlighted by Mushwana and Bezuidenhout (2014:62), is that the choice of platform accessed and data used should, as far as possible, be free from any defamatory remarks, deliberate criminal incitement, harassment or other offensive material. Our resources were, therefore, carefully selected and added to the rigour necessary and being time-consuming in the collection and analysis of the data. Sources with similar views and mutual messages conveyed are combined to form a specific narrative of the shared discourse of a group, and not as individual representations.

The ethical considerations concerning anonymity and confidentiality are, as far as possible addressed by ensuring that it applies to shared information, commentators, as well as the platforms and sources accessed. Steps to promote anonymity and confidentiality are further increased by ensuring that the research will not be harmful to anyone. In this regard, the value or benefit of this study is regarded as significant, as the BPA (2017:18) explains, anonymity and confidentiality are further achieved by maximising benefits, which in turn minimises harm. Researchers are responsible to assess any envisaged risk. This study is regarded as being of low risk because the method and methodology applied on this study adhere to the set ethical standards. Further to that, risk is assessed by evaluating the value of the contribution to the social and research community, and in this study, the significance of the value assessed is proportionate to any possible risk (Unisa 2016:31). Apart from any visible characteristics, information on a person's identity on social 
media is more than often hidden, anonymous or by using pseudonyms, which assists in securing any identifiable information. Another means to promote the ethics of our study is what the SRMG (2016:18) refers to as masking of the content, to secure individual's identities; however, the meaning of a message is still conveyed. The BPA (2017:11) describes this practice as anonymising data, as a prescribed means to ensure confidentiality. In this regard, representations from various sources were summarised and paraphrased. As researchers, we are committed to still convey the discourse of the public debates and discussions and reflect the shared stories of how COVID is experienced within a religious and spiritual narrative.

\section{COVID-19 as religious discourse}

Alienation between God and creation has been with humankind since the beginning of time, with 'the Fall' in the Garden of Eden as told in Genesis. Christians regard this as one of the most significant events of God's disappointment and how his image was 'defaced, though not obliterated'. For members of the Jewish tradition, 'the Flood' is regarded as the watershed moment in mounting grief and regret of God over his sinful people, and of his creation (Brett \& Goroncy 2020; Clauson 2015:8). In the last century, disasters such as earthquakes, tsunamis and hurricanes continue the discussions on an omnipotent and loving God. Similar questions are asked by followers of various religious denominations and orientations such as Christianity, Judaism, Islam on why bad happens to good people, why a just God permits such suffering (O'Mathúna 2018:27). The continuous discourse in this regard as described by Rouzati (2018:47) is, if God is the creator of all actions, is he then not accountable for all acts good and evil? This brings another dimension, namely the suffering as a result of evil between humans that has been the focus of most of the research studies and many discussions over the past decades (Chester \& Duncan 2009:305). Using theodicy as a philosophical framework, as researchers we acknowledge that it is not possible to attain definitive answers or solutions. The manner in which people interpret suffering is a way to make sense of what is happening and why. At the same time understanding their interpretation does not necessarily provide solace (Scott 2020:325).

This discourse, however, is not supported by all theorists. For example, Morgan and Wilkinson (2001:202) argue that the 20th century shifts to a 'modern consciousness' to intellectualise any actions and events to rationalise cause and effect. Philosophical theodicies are further described as people limiting their own critical reasoning. As these authors further elaborate, during past disasters, people's religious attributions made to their suffering were regarded by some as irrational and rather violating their beliefs in human dignity and a God of justice and truth. What our research, however, has shown is that COVID-19 has reactivated this debate in that it surpasses logic and rational thinking. This pandemic proves that scientists do not have all the answers, as is evident from a global surge in new transmissions from mid-June 2020, as well as changing characteristics and symptoms of this virus (Reuters 2020;
Evident from our findings from the numerous sources, discussions, sermons and comments are the rhetorical 'who' and 'why' questions asked. In that, just as scientists do not have all the solutions and cures, people also do not have religious or spiritual answers in their search on this phenomenon (Scott 2015:214). In a way, COVID becomes a spiritual virus, robbing humankind of its peace, beliefs and convictions, constantly fluctuating. These sentiments, as reflected in various sources consulted during this study, are summarised and paraphrased as follows:

'It is a roller coaster. I've moved from, this is God's way of warning us to align our lives, to who invented this virus, is there may be really a conspiracy, because it can't be real, to be deprived of everything some losing everything, to being angry to okay where is God, this is going on too long now, is this the end?'

It is such narratives that informed our findings and represented the different voices of people during this time. Our research aimed to gain some insight into people's religious views on the origin of COVID-19, the meaning they attach to the suffering caused by this pandemic and to explore how this impacts on their belief systems. To address this, the following themes were identified, namely (1) COVID-19 is an act of God, (2) COVID-19 has nothing to do with God and (3) God remains in control amidst a devastating pandemic. Subthemes identified will form part of the discussion of the findings to follow.

\section{Theme 1: COVID-19 is an act of God}

The origin of past events, natural disasters or pandemics is often attributed to some divine intervention by God to call upon His people. The suffering and pain it causes is interpreted through 'biblical narratives' to make sense of it (Scott 2011:151). Through the accounts shared, it is found how people rationalise their suffering and reaffirm God's caring omnipotence, and realising the meaning therein (Scott 2011:149).

Subtheme 1: There are no coincidences: One aspect identified from our sources is that there are no coincidences, something also found in research into past tragedies (Du Rand 2016:169; Gouw 2020). Some contributors view the timing of COVID as not coincidental, as they expressed:

'Only One can shut the world down like this, during the Holy Week for most Christians on the planet.' (P1)

'There is no coincidence that the major rise of COVID cases in the world was reported during Easter.' (P2)

'Ramadan had to change, maybe God is telling us something exactly at this significant time. It has renewed my focus. I have found new ways to get close to God.' (P3)

'Maybe God has a message. Being alone during Passover will be very different, but will remind me of so many in the past placed in concentration camps, and I realise how free I am, even during times of lockdown.' (P4)

'We are to withdraw from public places as at the Passover, go into our room and shut the door and wait until judgement passes.' (P4)

'Jesus rose to new life on Easter Sunday, and he is ever present, out of the darkness into the light revealing how committed he is to us also in these times.' (P6) 
Subtheme 2: Coronavirus disease is God's will: It is not uncommon that people tend to interpret natural disasters and epidemics as God's will. Tragedies are God's way to speak to his people and convey specific messages. Through such events, people are called to realise their imperfections and to turn to a willing God for help (O'Mathúna 2018:36-38) as was also found to be represented in many of the social media discussions:

'Adversity is the narrow place of refinement and chastisement. It is God's way to make us think about our faults and repent of our sins.' (P6)

'Adversity is God's call to do something great to re-evaluate our lives.' (P7)

'COVID and lockdown are my crossroads. When God has drawn the line in the sand and taken away all your choices, then you realise how you misjudged how big you think you were.' (P8)

Subtheme 3: COVID-19 is a reminder of the creator's teachings: Some findings of this study reflect people reminiscing about how the world keeps them occupied with meaningless and selfish accomplishments, forgetting their divine origin. Rouzati (2018:47) explains that times of adversity serve as a reminder of how people neglect the teachings of the Creator. Such tragedies are a harsh awakening sent as a reminder, and it is within this time that lives are restored and meaning is found, a notion shared by various discussions on platforms consulted in this study:

'I am ashamed that I thought I was doing good, giving and praying enough. How hard has He brought me to my knees with something so severe.' (P9)

'This is always a time of giving, but this Ramadan God taught us new, greater ways of giving.' (P10)

'As in the olden days, we are sanctioned, censored and forced to retreat to the sanctity of our homes to be alone with God for some time.' (P11)

Subtheme 4: Suffering is God's punishment: A further topic found relates to the attribution of this pandemic as God's wrath and punishment on his sinful and disobedient people. Natural disasters, over time, have been seen by people as a call to confess and pray to seek forgiveness for their sinfulness (Chester \& Duncan 2009:315). During the 2011 Japan earthquake and tsunami, similar sentiments were shared of these disasters being God's divine retribution on His people (Fujiwara 2013:18). The opinions shared on the various media platforms, often, show a brutal honesty, as if also a warning to others:

'There are many reasons why God has bestowed His rod on us, which many clergy has forgotten. It is because we have forgotten and not given due thanks.' (P10)

'These times remind ourselves that the anxiety of our hearts may be a symptom of self-governing rather than peace under the presence and knowledge of God.' (P1)

'This is His voice and we must listen, align and live in obedience at the sound of his voice.' (P11)
Subtheme 5: COVID-19 as retribution towards others: Similar narratives of COVID as punishment, also identified in this study, are projected as a form of retribution by 'our' God towards others who wronged them or are seen as a threat to humankind or their convictions. Chester and Duncan (2009:320) refer to this as 'retributive theodicy', as also represented in the findings:

'God, by His will, sent a punishment to tyrants of this time and their followers, which cannot be seen by the naked eye.' (P10)

'Be careful politicians and dictators, the powerless have an Almighty and He is not asleep, He sent COVID.' (P12)

'This is a God-sent to show the oppressors that they are not more powerful than His people.' (P13)

\section{Theme 2: COVID-19 has nothing to do with God}

As mentioned in earlier discussions in this article, the numerous narratives shared during the COVID pandemic on the cause of adversities are not dissimilar to other disasters that occurred over centuries. These times also regenerate heated debates on the origin of tragedies ranging between divine powers, God's omnipotence, karma, science, evil and even evolution. Previous disasters and pandemics are dissimilar regarding some characteristics, such as the biological epidemiology, but do share similarities with regard to the spiritual and psychological impact. Some aspects of COVID today, although still early days in the scientific empirical research, seem to give rise to similar social, religious and psychological discourses to those arising from other disasters at other times.

As research evolves on numerous diseases and illnesses, the information available escalates at a tremendous rate, volume and accessibility via the traditional media, but more in particular social media. As reported on the World Economic Forum-COVID Action Platform (Neri 2020), one would expect that with advances in the scientific and medical fields, technology, communication networks and even literacy, allowing access to vast amounts of data and sources will enhance our understanding of this phenomenon. However, what our research shows is that such advances allow many more role players in the COVID arena. This results in an increase in opposing opinions, voices and debate on other issues such as God versus nature, faith versus science, facts versus conspiracy and politics versus humanity.

Subtheme 1: Darkness versus light: Voices shared during this study, on the matter of other forces than God as an origin for COVID, are often narrated as a play between dark and light to make sense of this invisible, deceptive and unpalatable virus and unknown force (University of Rhode Island 2020) as represented in various discussions:

'There is nothing sinister about this. Why are people now uncomfortable and scared? This is the course of nature and life.' (P14)

'You say, but I can't see the evil, but I ask when can you ever see it?' (P10) 
'The darkness has eventually caught up with the human race. Where is 'the light' you are all talking about?' (P15)

'This is caused by demonic forces just as other disasters.'

'Nature is taking revenge on the destructiveness of the world as with all other hurricanes, floods, fires, tsunamis and volcanic eruptions.' (P16)

Subtheme 2: COVID-19 as a cause of conspiracies: Even though not much information was available during past pandemics, centuries later more insights are gained into the epidemiology, pathogens and transmission of these pandemics. Previously, information of such adversities was mainly conveyed by scientists and physicians, but today politicians, theologians, religious leaders, the media and the public play a more prominent role. Not that it did not exist during other tragedies, but the mere speed and volume at which information is distributed are incomparable. As with our findings, this, however, creates even more confusion and new theories of other conspiracies. This shaped many discussions that postulated a deliberate cause of this pandemic, as we found during this study:

'The many religious role players fighting the COVID-19 dilemma today cannot even work peacefully during normal times. What is all too visible is the absence of the so-called spiritual leaders.' (P18)

'It is not difficult to see that other higher powers are at play here, not divine, but political, which cause economies to crash. It even quiets the religious clergy.' (P19)

'It is clear that this is a biological war between the East and the West at the cost of every human being. History is just repeating itself.' (P20)

'Even the spirituals are scared and do not know what is happening. They realise that this has nothing to do with their God.' (P15)

'Just as with the Black Death, this pandemic also comes from the East.' (P21)

Subtheme 3: Job as the forgotten soul during his suffering: During this study, the Job narrative is often brought into the religious discourse, particularly in opposing poles of the COVID continuum. The absence of God in this pandemic (Scott 2020:321) is also identified as a topic of debate, summarised as follows:

'All the references to having faith like Job, what does that mean? Is it not that his God was absent when he suffered the most. Is it not that today you still do not understand how your almighty God causes you suffering, yet you say he is the one who allows it and will save you?' (P15)

'The Job-legacy will not take you far with this pandemic.' (P18)

Subtheme 4: Science is the answer to COVID-19 not religion: The many opposing views collected in our research support the notion expressed by Marshall (2020) that this pandemic should be removed from worldviews on spirituality and religion. Religiosity is further regarded as the biases that misrepresent the facts, data and the current discourse. This inevitably leads to the rude question, as posted on various media platforms accessed in this study, Can faith and science go together? This proves to be still paramount and elicits even more responses today, as narrated by numerous debates found during the research in this study:

'With all the educational acumen amongst all these people of religion, they do not even comprehend the logic and rationality of this pandemic.' (P15)

'So how will the blood of Jesus cleanse you against this virus? Why will you be saved, because you are sinless and morally better than others?' (P18)

'It is dark forces that use science to destroy the world to take control of all countries, economies and resources.' (P16)

'It is not difficult for people to understand that it is purely science, and it has nothing to do with any God.' (P22)

'There is a weird scientific agenda behind this; even the medical practitioners are confused. No, it is something worse than even an atomic bomb.' (P21)

Subtheme 5: Religion does not provide any answers to COVID-19: The other burning question raised from the various sources consulted is, So where is your God now? inviting many debates as found during this study. The media used to communicate, as identified in our research, enable and encourage open discussions that contribute to the richness of the data collected. A matter identified is that many of these expressions come with a lot of anger, directed to others, such as:

'Let us not mix science and faith and let us not confuse common sense with religion.' (P22)

'This is typical of people fixated on some omnipotent superior power, resulting in irrational thinking, causing irresponsible behaviour by their followers. Who then sits back and says it is God's will, whilst it is them that spread the virus.' (P15)

'You preach that your God is in control of everything, so he caused all this misery, poverty and deaths?' (P)

'Your religion and faith is totally misplaced. Why are all you the so-called believers not saved?'

Subtheme 6: COVID-19 is not a matter of science versus faith: From the findings, many do not regard COVID as a matter of science versus faith or religion. People tend to acknowledge the prominent role science plays in this pandemic. The significance of the many debates followed during this study is that they display some shift from archaic beliefs that the origin of suffering and tragedy has only one cause (McLaughlin 2016:127). The narratives shared from the sources consulted describe it as more of a binary relationship:

'As a Christian, I believe this is science gone wrong, but God permits it, because He remains in control.' (P17)

'To understand the science beyond COVID does not make me less religious.' (P23)

'My faith helps me understand the science behind this pandemic. Science is created by God as well, is it not?' (P13)

'The science is simple, it comes from bats, rats and who knows what else humans eat. God gave us the mental capacity to know better and to understand this.' (P22) 
Subtheme 7: Suffering is caused by people's self-centredness: Discussions such as the aforementioned brought other perceptions or philosophies to the fore, which did not reflect as we versus them or good versus evil discourse. It takes the approach that all suffering and adversity are a result of unfulfilled desires, because of our focus on individuality and self-centredness, believing that we can survive independently from others (Maritz 2020). Representations found in this regard were typically from followers of Buddhism, for example. The discussion, however, was not limited to those and provided some significant interactions:

'This pandemic is caused by humans' struggle with attachments to worldly materialism. It is man's inability to detach him or herself from the so-called significant relationships, thinking other people are most important in your lives. Adversity is caused as a wake-up call to free yourself from yourself and your needs and desires.' (P6)

'All the calls by people, such as and add inverted commas from "I can't live ... day", that is alarming. Maybe the universe is telling us something and we brought this unto ourselves.' (P7)

'All is to boost your ego to feel good to renounce such important attachments, yet losing your inner self. COVID-19 is a call for inner peace.' (P1)

Subtheme 8: The universe punishes disharmony: These narratives furthermore relate to our interdependence, however, not a dependency, upon all in the universe and how the ills in other parts of the world directly impact on us all (Amodeo 2020). Du Rand (2016:170) also refers to this as a striving to answer the theodicies of the 'why' in regarding all as part of the larger universe. In African religious traditions, this is also a belief that punishment is bestowed upon people by ancestors, because of them causing disharmony in the universe (Magesa 1997:n.p.; Nsengiyumva 2016:223-224). It is about harmony and balance as the shared stories suggest:

'COVID is caused by people's inability to strive for inner peace, which in turn results in an imbalance in the universe.' (P7)

'Because everything is interconnected, balance is important to avoid tragedies and disasters. And, all in the world caused the imbalances that resulted in this pandemic.' (P24)

'Being a Christian, I can see how the imbalances in the world can cause this adversity. Our negligence and being too self-possessed with our inner circle and needs, forgetting about our impact on others, the world, nature and other beings, have disastrous effects brought on by our forebearers.' (P8)

'Causing harm to the cosmic harmony upsets our ancestors, and their punishment can come in many forms such as disease.' (P10)

\section{Theme 3: God remains in control, no matter the cause of COVID-19}

A further significant discourse identified during our research is that irrespective of what or who causes adversity, many representations voice that bad happens to everyone whether you believe or not. It is how you respond to it that matters. Whilst this pandemic is still rampant, causing much grief, people are in a continuous process of making sense of it all.
Subtheme 1: God remains omnipotent and trustworthy: People are trying to reconcile their pain, fears and the bad that is happening with the omnipotent and love of God, and their part in his greater divine plan (Scott 2011:149). Tragic events often force people to keep faith that God remains constant and trustworthy, as voiced in our study as a further prominent message:

'You are only the creation, not the Creator. The important message is that you might get ill and may recover, it is all temporary. Life is not what it seems, there is more constancy in God.' (P12)

Even in uncertain times we know that God's peace, which transcends all understanding, will guard our hearts and minds.' (P2)

'This will not shake nor break us, you are his treasure.' (P2)

'We don't need to have the answers. Jesus is the answer in every season or adversity.' (P13)

Subtheme 2: God remains in control even of COVID-19: The above narratives convey a significant message on the meaning people attach to events, and their lives during this challenging time. It is looking beyond what is happening and accepting that God is in control. It also serves as a survival mechanism, as some expressions in this study showed that it is time to see the bigger picture that God is in control, no matter how bad the situation is:

'We cannot keep on asking why? We have to believe his word and his promises.' (P5)

'In these times, we must remember to be quiet and focus on the sheep in the presence of their Shepherd.' (P4)

Subtheme 3: Having faith like Job during COVID-19: Many narratives, identified in this study, are concluded by reminiscing about Job's suffering, his spiritual journey and relationship with God, as summarised by the following representations:

'Like Job, I will not lose faith and keep my eye on God.' (P4)

'God will not fail me as with Job in his darkest times, God always provided.' (P5)

'One did not always understand how Job could overcome so much suffering and still be faithful.' (P13)

'Some days I am angry and cannot accept that God will allow his children to lose so much, jobs, livelihood, lives. But some days, I do understand and ask why, but realise $\mathrm{He}$ is all we have. We do not have any choice but to hold tight onto Him.' (P2)

From the various comments by, and debates between participants on the topic of the origin, meaning making, and suffering caused by this pandemic, it was noticeable. Many expressed how this pandemic tests them to limits they never knew. Coronavirus disease is not a once-off event, and people are surrounded by live announcements of rising cases, rising deaths and failing economies and most are left disillusioned. However, the majority of messages form part of a similar discourse, of the world is in this together and despair is not an option. In the construction of the reasons whether spiritual, religious or non-religious is 
a way of sense making and finding solace during these most challenging times.

\section{Conclusion}

This article explores narratives shared during the global COVID-19 peak from April to July 2020 on various social media platforms. It aims at providing insight into people's religious views on the origin of this pandemic to reflect on the meaning they attach to their suffering caused by this pandemic and explore how this pandemic impacts on their belief systems. Coronavirus disease 2019 differs from other pandemics, firstly in the rapid global transmission, and secondly in the large amounts of information available and accessible, as well as the vast global spread via social media. Scientific and technological advances contribute to a better understanding of this phenomenon. Our research shows, however, that these advances allow much more role players in the COVID arena. This results in increasing opinions, voices and debate, and it is evident from our findings that the global population, at some time during this pandemic, asks the same rhetorical 'who' and 'why' questions.

One significant finding is that COVID-19 is not only a physical virus but becomes also a spiritual virus that in some instances robs people of their peace, beliefs and convictions. Another concept highlighted is that irrespective of people's religious convictions, religious denomination or spiritual belief systems, they tend to share similar views. People also do not necessarily speak from a basis of, for example, their church structure.

Our findings are represented by paraphrased summaries of the shared narratives. Using theodicy as the philosophical framework relates to the significant spiritual discourses identified, divided into three themes and subthemes:

- On the first theme, COVID-19 being an act of God, comments reflect that there is no coincidence in the time that all countries were mostly affected which is during Easter, Passover and Ramadan. These events are the framework in which many people rationalise their suffering and reaffirm his love and omnipotence.

- Coronavirus disease is not regarded as having a scientific or biological basis, but is rather a divine, godly intervention.

- It is God's way to remind us of how we neglect the teachings of our Creator.

- This pandemic is also attributed to the wrath of God on his disobedient and sinful people, and a call to confess and pray for forgiveness.

- It is also seen as retribution directed towards others, such as politicians, oppressors and tyrants, who cause human suffering.

- The second theme renounces God as the origin of COVID-19, but attributes it to the elements of God versus nature, faith versus science, facts versus conspiracy and politics versus humanity. Some narratives shared relate to dark, invisible forces as the origin.
- Theories of conspiracy, for political and economic gain, are connected as deliberate cause of this pandemic.

- Comparison to the suffering of Job is also identified as a topic of debate, particularly the absence of God during his suffering, as he is absent during this pandemic.

- Some representations plead that this pandemic should be removed from worldviews on spirituality and religion, because religiosity encourages misrepresentation of facts. The question is once again asked whether faith and science can go together, and science is rather regarded as the answer to COVID.

- A further discourse identified is the anger directed towards the religious views, posing the question, 'So where is your God?' Some expressions relate to how irrational and misplaced faith is the cause for the spread of the virus.

- Some, however, acknowledge that it is not a matter of science versus faith or religion but it allows for a binary relationship.

- Other origins of COVID-19 are further attributed to the universe's reaction to our self-centredness, individualistic tendencies and desires for worldly possessions.

- The aforementioned also relates to the belief that the world is punished because of the disharmony caused, and the disregard for the interconnectedness of everything and everyone.

- The third theme regards the notion of God who remains in control, no matter the cause of this pandemic.

- People are reconciling their suffering with a loving God and acknowledging we are part of his greater divine plan.

- People make sense of these challenging times by looking beyond the misery caused by COVID and believe that God is in control.

- Many concluding discussions display the other side of the similarities drawn with the story of Job. The current challenging times faced are compared with Job's suffering, and his spiritual journey and relationship with God.

During these challenging times, some might regard the 20th century as a new era towards a more intellectualised, rationalised interpretation of natural disasters (Morgan \& Wilkinson 2001:202). This study, however, illustrates a strong notion towards the prominent role of God in all these adversities. Coronavirus disease 2019 has reactivated this debate in that it surpasses logic and rational thinking. It further explored how, during COVID-19, emotions constantly fluctuate between losing sight and insight, misunderstanding and understanding and fear and hope. It is the time of one's own sense and meaning-making, and the stories collected reflect very personal journeys during this time. Each one deals with this pandemic in a different way, and all the stories shared reveal many different answers to the why and who as the cause of this pandemic. 


\section{Acknowledgements Competing interests}

The authors have declared that no competing interest exists.

\section{Authors' contribution}

All authors contributed equally to this work.

\section{Ethical considerations}

This article followed all ethical standards for carrying out research without direct contact with human or animal subjects.

\section{Funding information}

This research received no specific grant from any funding agency in the public, commercial or not-for-profit sectors.

\section{Data availability}

The data are restricted because of online media platform policies to limit any compromise to content and users.

\section{Disclaimer}

The views and opinions expressed in this article are those of the authors and do not necessarily reflect the official policy or position of any affiliated agency of the authors.

\section{References}

Amodeo, J., 2020, 'How the coronavirus helps us understand the Buddhist view of our interdependence', PsychCentral, viewed 21 June 2020, from https://psychcentral. $\mathrm{com} / \mathrm{blog} /$ how-the-coronavirus-helps-us-understand-the-buddhist-view-of-ourcom/blog/how-the-ce
interdependence/.

Brett, M. \& Goroncy, J., 2020, 'Coronavirus, creation and the creator: What the Bible says about suffering and evil', ABC Religion \& Ethics, viewed 21 June 2020, from https://www.abc.net.au/religion/coronavirus-creation-and-the-creator-biblicalhttps://www.abc.net.au/religion
faith-and-problem/12200508.

British Psychological Society, 2017, Ethics guidelines for Internet-mediated research, INF206/04.2017, viewed 10 July 2020, from https://www.bps.org.uk/sites/www. bps.org.uk/files/Policy/Policy\%20-\%20Files/Ethics\%20Guidelines\%20for\%20 Internet-mediated\%20Research\%20(2017).pdf.

Byrnes, K.G., Kiely, P.A., Dunne, C.P., Kieran, W., McDermott, K.W. \& Coffey, J.C., 2020, "Communication, collaboration and contagion: "Virtualisation" of anatomy during COVID-19', Clinical Anatomy 34(1), 82-89. https://doi.org/10.1002/ca.23649

Chester, D.K. \& Duncan, A.M., 2009, 'The Bible, theodicy and Christian responses to historic and contemporary earthquakes and volcanic eruptions', Environmental Hazards: Human and Policy Dimensions 8(4), 304-332. https://doi.org/10.3763/ ehaz.2009.0025

Clandinin, D.J., 2006, Narrative inquiry: A methodology for studying lived experience Research Studies in Music Education 27(1), 44-54. https://doi.org/10.1177/1321 103X060270010301

Clandinin, D.J., 2007, Handbook of narrative inquiry: Mapping a methodology, Sage, London.

Clauson, M.A., 2015, 'Human nature and the Christian', History and Government Faculty Publications 169, 7-21, viewed 05 July 2020, from http://digitalcommons. cedarville.edu/history_and_government_publications/169.

Conradie, E.M., 2005, 'HIV/AIDS and human suffering: Where on earth is God?', Scriptura 89, 406-432. https://doi.org/10.7833/89-0-1027

Du Rand, J.A., 2016, 'The mystery in theodicy', Neotestamentica 50(3), 167-186. https://doi.org/10.1353/neo.2016.0023

Fujiwara, S., 2013, 'Reconsidering the concept of theodicy in the context of the post2011 Japanese earthquake and Tsunami', Religion 43(4), 499-518. https://doi.org /10.1080/0048721X.2013.779614

Gouw, A., 2020, 'Did God "let" COVID-19 happen?', Sinai and Synapses, viewed 22 June 2020, from https://sinaiandsynapses.org/multimedia-archive/did-godlet-covid-19-happen/.
Landman, C. \& Pieterse, T., 2019, '(Re)constructing God to find meaning in suffering: Men serving long-term sentences in Zonderwater', HTS Teologiese Studies/ Theological Studies 75(4), a5520, 1-10. https://doi.org/10.4102/hts.v75i4.5520

Leibniz, G.W., 2005, Theodicy: Essays on the goodness of God the freedom of man and the origin of evil, transl. E.M. Huggard, Open Court Publishing Company, IL, viewed 24 June 2020, from https://archive.org/stream/theodicy17147gut/17147.txt.

Magesa, L., 1997, African religion: The moral traditions of abundant life, Orbis Books, Maryknoll, New York.

Maritz, D., 2020, 'COVID-19: Is God to blame?', SATS Bible based, Christ centred, Spirit led, viewed 23 June 2020, from https://www.sats.edu.za/blog/2020/04/08/covid19-is-god-to-blame-by-daniel-maritz/.

Marshall, K., 2020, 'What religion can offer in the response to COVID-19', World Politics Review, viewed 29 June 2020, from https://www.worldpoliticsreview. com/articles/28789/what-religion-can-offer-in-the-response-to-covid-19.

McLaughlin, 2016, 'Hard lessons learned: Tracking changes in media presentations of religion and religious aid mobilization after the 1995 and 2011 disasters in Japan', Asian Ethnology 75(1), 105-137. https://doi.org/10.18874/ae.75.1.05

Meylahn, J.A., 2020, 'Being human in the time of Covid-19', HTS Teologiese Studies/ Theological Studies 76(1), a6029. https://doi.org/10.4102/hts.v76i1.6029

Morgan, D. \& Wilkinson, I., 2001, 'The problem of suffering and the sociological task of theodicy', European Journal of Social Theory 4(2), 199-214. https://doi. org/10.1177/13684310122225073

Mushwana, G. \& Bezuidenhout, H., 2014, 'Social media policy in South Africa', Southern African Journal of Accountability and Auditing Research 16, 63-74, viewed 29 June African Journal of Accountability and Auditing Research 16, 63-74, viewed 29 Jttps://repository.up.ac.za/bitstream/handle/2263/45395/ Mushwana_Social_2014.pdf?sequence=1.

Neri, A., 2020, 'How COVID-19 ended the information era and ushered in the age of insight', World Economic Forum, viewed 20 July 2020, from https://www. insight, World Economic Forum, viewed 20 July 2020, from https://www. ushered-in-the-age-of-insight/.

Newman, T., 2020, 'Comparing COVID-19 with previous pandemics', Medical News Today, 19 April, viewed 23 June 2020, from https://www.medicalnewstoday.com/ articles/comparing-covid-19-with-previous-pandemics\#The-many-returns-ofarticles/con
cholera.

Nsengiyumva, L.S.J., 2016, 'Supporting the ethics of abundant life in Africa: A threepillar framework from the Beatitudes in Matthew 5', Hekima Review (55), viewed 03 July 2020, from https://www.researchgate.net/publication/314499902.

O'Mathúna, D.P., 2018, 'Christian theology and disasters: Where is God in all this?', in D.P. O'Mathúna (ed.), Disasters: Core concepts and ethical theories, pp. 27-24, Springer, Dordrecht.

Pulido, C.M., Ruiz-Eugenio, L., Redondo-Sama, G. \& Villarejo-Carballido, B., 2020, 'A new application of social impact in social media for overcoming fake news in health', International Journal of Environmental Research and Public Health 17(2430), 1-15. https://doi.org/10.3390/ijerph17072430

Reuters, 2020, 'New WHO guidance calls for more evidence on airborne transmission', Eyewitness News, viewed 15 July 2020, from https://ewn.co.za/2020/07/09/newwho-guidance-calls-for-more-evidence-on-airborne-transmission.

Rouzati, N., 2018, 'Evil and human suffering in Islamic thought - Towards a mystical theodicy', Religions 9(2), 47. https://doi.org/10.3390/rel9020047

Scott, M.S.M., 2011, 'Theodicy at the margins: New trajectories for the problem of evil', Theology Today 68(2), 149-152. https://doi.org/10.1177/0040573611405878

Scott, M.S.M., 2015, Pathways in theodicy: An introduction to the problem of evil, Fortress Press, Minneapolis, MN.

Scott, M.S.M., 2020, 'Befriending job: Theodicy amid the ashes', Open Theology 6(1), 319-326. https://doi.org/10.1515/opth-2020-0022

Social Media Research Group, 2016, 'Using social media for social research: An introduction', Government Social Research: Social Science in Government, viewed 12 July 2020, form https://assets.publishing.service.gov.uk/ government/uploads/system/uploads/attachment data/file/524750/GSR Social_Media_Research_Guidance_-_Using_social_media_for_social_ recial_Mediph.pdf.

Townsend, L. \& Wallace, C., 2016, Social media research: A guide to ethics, University of Aberdeen, viewed 20 July 2020, from www.gla.ac.uk/media/media_487729_en.pdf.

University of Rhode Island, 2020, 'Comparing COVID-19 to pandemics of the middle ages', Medical Express, viewed 10 July 2020, from https://medicalxpress.com/ news/2020-04-covid-pandemics-middle-ages.html.

University of South Africa (Unisa), 2016, Policy on research ethics, University of South Africa, Pretoria.

WHO, 2020a, Novel coronavirus - China, viewed 10 July 2020, from https://www.who. int/csr/don/12-january-2020-novel-coronavirus-china/en/.

WHO, 2020b, Pneumonia of unknown cause - China, viewed 10 July 2020, from https://www.who.int/csr/don/05-january-2020-pneumonia-of-unkown-causechina/en/.

WHO, 2020c, Naming the coronavirus disease (COVID-19) and the virus that causes it, viewed 10 July 2020, from https://www.who.int/emergencies/diseases/novelcoronavirus-2019/technical-guidance/naming-the-coronavirus-disease(covid-2019)-and-the-virus-that-causes-it.

Worldometers, 2020, CovID-19 coronavirus pandemic, viewed 10 July 2020, from https://www.worldometers.info/coronavirus/. 